ВИВЧЕННЯ ГЕНДЕРНИХ ОСОБЛИВОСТЕЙ ОСОБИСТОСТІ СПОРТСМЕНІВ (НА ПРИКЛАДІ КАРАТЕ ТА НАСТІЛЬНОГО ТЕНІСУ) ТА ОСІБ, ЯКІ НЕ ЗАЙМАЮТЬСЯ СПОРТОМ

\title{
DETERMINATION OF GENDER CHARACTERISTICS OF THE PERSONALITY OF ATHLETES AND PERSONS WHO DO NOT GO IN FOR SPORTS (ON THE EXAMPLE OF KARAT AND TABLE TENNIS)
}

УДК 796.012.2+796.077.5:796.322 DOI https://doi.org/10.32843/26635208.2021.23.27

Реут Є.О.

старший викладач кафедри орізичного виховання та спорту Національний технічний університет «Дніпровська політехніка»

Крючков C.I.

старший викладач кафредри фізичного виховання та спорту Національний технічний університет «Дніпровська політехніка»
Статтю присвячено тематиці гендерної ідентичності, яка $є$ одним із важливих компонентів самоідентифрікації індивіда. Для спортивної діяльності маскулінні якоcmi в дівчат-спортсменок $\epsilon$ показником успішності. Однак за межами спортивної діяльності маскулінні якості дівчат можуть знижувати есрективність міжособистісних взаємин. У зв'язку із цим дослідження гендерної дисреренціації представників різних видів спорту на прикладі карате й настільного тенісу з урахуванням фрактора статі представляється своєчасним та актуальним. У статті розглядаються питання визначення психологічної статі за методикою С. Бем. Така методика використовується також для визначення ступенів андрогінності, маскулінності й фремінності особистості. У дослідженнях використовувались такі методи: аналіз та узагальнення літературних джерел та інтернет-ресурсів із досліджуваної проблеми; методика С. Бем «Маскулінність / фремінність»; методи математичної статистики. У дослідженнях взяло участь 106 осіб, спортсменів Національного технічного університету «Дніпровська політехніка», дівчат - 56 осіб, юнаків - 50. Спортсмени це представники таких видів спорту, як карате й настільний теніс. Вік обстежуваних - 17-23 роки. Певно встановлено, що в дівчат-спортсменок до маскулінного типу ідентифрікації особистості віднесено 20\% обстежуваних, до андрогінного - 80\%. У тих, що не займаються спортом, до фемінінності належить $6 \%$, до маскулінності й андрогінності - 12\% і 82\% відповідно. У досліджуваних групах дівчат домінує маскулінний та андрогінний типи гендерноі ідентичрікації особистості. Маскулінність проявилася в 30\% юнаків, андрогінність -у 70\%. У досліджуваних групах обох статей досить вагомим виявлено відсоток андрогінного типу особистості. На наш погляд, такі отримані дані можуть свідчити про адаптивні фрактори до занять спортом.
Ключові слова: гендер, маскулінність, фремінінність, андрогін, спортсмени, карате, настільний теніс, психодіагностика, методика С. Бем.

Gender identity is one of the important components of an individual's self-identification. For sports activities, masculine qualities in girlsathletes are an indicator of success. However, outside of sports, the masculine qualities of girls can reduce the effectiveness of interpersonal relationships. In this regard, the study of gender differentiation of different sports on the example of karate and table tennis, is timely relevant. The article considers the issues of determining the psychological sex according to the method of S. Bem. This technique is also used to determine the degrees of androgyny, masculinity and femininity of the individual. The following methods were used in the research: analysis and generalization of literature sources and Internet resources on the researched problem; S. Bem's method "Masculinity / femininity"; methods of mathematical statistics. The research involved 106 people, athletes from the National Technical University "Dnipro Polytechnic", girls - 56 people, boys - 50 . Athletes are representatives of such sports as karate and table tennis. The age of the subjects is 17-23 years. It is reliably established that in female athletes $20 \%$ of the subjects belong to the masculine type of identification, and $80 \%$ to androgynous. In those who do not play sports to femininity - $6 \%$, masculinity and androgyny $12 \%$ and $82 \%$ respectively. The studied groups of girls are dominated by masculine and androgynous types of gender identity. Masculinity was manifested in 30\% of young men and androgyny in $70 \%$. In the study groups of both sexes, the percentage of androgynous personality type was found to be quite significant. In our opinion, such data may indicate adaptive factors for sports.

Key words: gender, masculinity, femininity, androgyny, athletes, karate, table tennis, psychodiagnostics, method of S. Bem.
Постановка проблеми. За даними низки авторів, протягом тривалого часу чоловіків і жінок розподіляли тільки за анатомічними ознаками. Дещо пізніше ввели поняття «гендер» [4, с. 58].

Проблема формування маскулінності / фемінінності викликає багато суперечок і розбіжностей, зокрема в питанні про те, чи є такий особистісний компонент вродженим або придбаним у ході розвитку особистості [2, с. 190].

Питання гендерної ідентифікації особистості продовжують залишатися актуальними, й сфера спорту не є винятком. Як відомо, гендерна ідентичність $€$ одним із важливих компонентів самоідентифікації індивіда. У процесі гендерної соціалізації основними є орієнтири, які визначаються суспільством як «чоловіче» й «жіноче» [1, с. 12].

Постановка завдання. Метою статті є вивчення гендерних особливостей особистості спортсменів (на прикладі карате й настільного тенісу) й осіб, які не займаються спортом.

Виклад основного матеріалу дослідження. У зв'язку з розширенням жіночих спортивних дисциплін, а також участі жінок у тих видах спорту, які раніше вважалися суто чоловічими, на перший план висувається безліч питань. Наприклад, яким чином заняття тим чи іншим видом спорту впливає на зміну структури їхньої особистості. У тих видах спорту й дисциплінах, які раніше вважалися 
суто чоловічими, спортсменки проявляють нетипові особливості поведінки, а не загальноприйняті [6, с. $168 ; 11$, с. 4]

Для спортивної діяльності маскулінні якості в дівчат-спортсменок $є$ показником успішності. Однак за межами спортивної діяльності маскулінні якості дівчат можуть знижувати ефективність міжособистісних взаємин [3, с. 22].

У зв'язку із цим дослідження гендерної диференціації представників різних видів спорту на прикладі карате й настільного тенісу з урахуванням фактора статі представляється своєчасним та актуальним.

У людини безліч психологічних рис характеру, деякі з них є універсальними. Інші традиційно пов'язуються з типово чоловічою або типово жіночою психологією. Наприклад, рівень агресивності й домінантності розглядаються як типово чоловічі риси.

у процесі виховання та розвитку особистості, а також соціалізації формуються інші риси. Не випадково ж існують соціальні стереотипи маскулінності й фемінності [9, с. 20].

У науці заведено говорити про феномен «психологічна стать» - маскулінність, фемінність, андрогін. До типово чоловічих рис (маскулінність) традиційно належать такі риси, як незалежність, наполегливість, домінантність, агресивність, схильність до ризику, самостійність, впевненість у собі тощо [5, с. $185 ; 6$, с. 168].

До типово жіночих рис, тобто фемінності, традиційно належать такі риси, як поступливість, м'якість, чутливість, сором'язливість, ніжність, здатність до співчуття, співпереживання тощо. Соціальні стереотипи фемінності менше стосуються польових сторін особистості й успішності ділової кар'єри, але водночас приділяють значну увагу емоційним аспектам. Про андрогіна кажуть у тих випадках, коли індивід не володіє чітко вираженою психологічною маскулінністю або фемінністю. У представників-андрогенів ці риси представлені гармонійно й взаємодоповнювано. Вважається, що така гармонійна інтеграція маскулінних і фемінних рис підвищує адаптивні можливості андрогінного типу [7, с. $167 ; 8$, с. 201].

Однак м'якість, стійкість у житті й відсутність різко виражених агресивних тенденцій у спілкуванні не можна пов'язувати зі зниженням впевненості в собі. Тому що навпаки, вони проявляються на тлі самосприйняття, збереження високої самоповаги, впевненості в собі.

У процесі наших досліджень спортсменам було запропоновано методику на визначення психологічної статі за С. Бем. (Sandra L. Bem, 1974), яка використовується для здійснення діагностики психологічної статі, а також визначає ступінь андрогінності, маскулінності й фемінності особистості [13, с. 65].

Опитувальник складається із 60 тверджень (якостей), на кожне з яких випробуваний відповідає тільки «так» або «ні». Тим самим кожен випробовуваний оцінює в собі наявність або відсутність перерахованих якостей.
Якщо величина індексу IS укладена в межах від - 1 до +1, то роблять висновок про андрогінність. Якщо індекс IS менше ніж -1, то робиться висновок про маскулінність. А якщо індекс IS більше ніж +1 - про фемінність. Водночас у разі, коли IS менше ніж -2,025, говорять про яскраво виражену маскулінність. А якщо IS більше ніж $+2,025$, кажуть про яскраво виражену фемінність.

Розглянемо стандартні значення індексу IS. Яскраво виражена маскулінність має значення понад -2, проста маскулінність коливається в межах від -2 до -1, андрогінність від -1 до 1, фемінність від 1 до 2, яскраво виражена фемінність - понад $2[3$, c. 58].

Маскулінні якості: діє як лідер, агресивний, честолюбний, аналітичний розум, напористий, розумний, любить змагатися, захищає свої переконання, домінантний, сильний, має здібності лідера, незалежний, індивідуалістичний, легко приймає рішення, мужній, сподівається тільки на себе, самодостатній, сильна особистість, бажає мати певну позицію, любить ризик.

Фемінні якості: ніжний, веселий, схожий на дитину, жалісливий, не користується грубими словами, готовий втішати інших, жіночний, любить лестощі, добрий, довірливий, любить дітей, вірний, уважний до потреб інших, сором'язливий, вкрадливий, той, що співчуває, ніжний, той, що розуміє, серцевий, поступливий.

Нейтральні якості: вміє пристосовуватися, марнославний, сумлінний, ввічливий, доброзичливий, щасливий, готовий надати допомогу, невмілий, ревнивий, приємний, легко піддається змінам настрою, надійний, потайний, щирий, серйозний, тактовний, театральний, правдивий, непередбачений, неорганізований [10, с. 116].

Конкретніше диференціювання випробовуваних, за даними Е. Пайнс і К. Маслач, можна здійснити відповідно до класифікації типів статеворольової ідентичності:

1) гіпермаскулінний тип: поєднання дуже високого рівня маскулінності (80-100\% із 20 пред'явлених індивіду маскулінних якостей);

2) маскулінний тип: поєднання помірно високого рівня маскулінності й низького - фемінності $(-2,025<\mathrm{t} \leq-1)$;

3) фемінний тип: поєднання помірно високого показника фемінності й низького - маскулінності $(1<\mathrm{t}<2,025)$;

4) гіперфемінний тип: поєднання дуже високого рівня фемінності (80-100\% фемінних якостей із 20 можливих) і низького рівня маскулінності ( $\mathrm{t} \geq 2,025)$;

5) андрогін: поєднання однаково високих значень маскулінності й фемінності (50\% і більше маскулінних і 50\% і більше - фемінних якостей із 20) $(-1 \leq \mathrm{t} \leq 1)$;

6) недиференційований тип (низький рівень андрогін): поєднання однаково низьких значень маскулінності й фемінності (не більше 30-40\% маскулінних і не більше 30-40\% фемінних якостей із 20 можливих $(-1 \leq \mathrm{t} \leq 1)$ [8, с. 201]. 
Отримані показники за результатами ідентифікації особистості

\begin{tabular}{|c|c|c|c|c|}
\hline $\begin{array}{c}\text { Гендерний тип } \\
\text { особистості }\end{array}$ & $\begin{array}{c}\text { Дівчата- } \\
\text { спортсменки, \% } \\
\text { (n=56) }\end{array}$ & $\begin{array}{c}\text { Ti, що не } \\
\text { займаються } \\
\text { спортом, \% } \\
\text { (n=56) }\end{array}$ & $\begin{array}{c}\text { Юнаки- } \\
\text { спортсмени, \% } \\
\text { (n=50) }\end{array}$ & $\begin{array}{c}\text { Ti, що } \\
\text { не займаються } \\
\text { спортом, \% } \\
\text { (n=50) }\end{array}$ \\
\hline Андрогін & 80 & 82 & 70 & 80 \\
\hline Фемінність & - & 6 & - & - \\
\hline Маскулінність & 20 & $12 \%$ & 30 & 20 \\
\hline
\end{tabular}

За даними низки авторів, поєднане застосування психодіагностичного тестування опитувальника С. Бем із результатами інших особистісних опитувальників може дозволити отримати точніші результати в психодіагностиці індивідуально-особистісних характеристик досліджуваних $[4$, c. $58 ; 12$, с. 201].

Мета - визначення гендерного типу особистості спортсменів та осіб, що не займаються спортом, за допомогою психодіагностичного тестування за методикою С. Бем.

Методи дослідження: аналіз та узагальнення літературних джерел та інтернет-ресурсів із досліджуваної проблеми; психологічні методи: методика С. Бем «Маскулінність / фемінність»; методи математичної статистики.

У наших дослідженнях взяло участь 106 осіб це спортсмени-студенти Національного технічного університету «Дніпровська політехніка» віком від 17 до 23 років. Дівчат - 56 осіб, юнаків - 50, представники карате й настільного тенісу.

Певно встановлено, що в дівчат-спортсменок до маскулінного типу ідентифікації особистості віднесено $20 \%$ обстежуваних, до андрогіна - $80 \%$. У тих, що не займаються спортом, до фемінності належать 6\% (табл. 1).

Ідентифікація особистості людини формується протягом усього життя. Спортивна діяльність впливає на її формування. На підставі результату опитування можна зробити висновок, що маскулінність проявилася в 30\% (юнаки), андрогін - в юнаків у 70\%. Тобто в досліджуваних групах дівчат домінує маскулінний і андрогінний типи гендерної ідентифікації особистості. У досліджуваних групах обох статей досить вагомим виявлено відсоток андрогінного типу особистості. На наш погляд, такі отримані дані можуть свідчити про адаптивні фактори до занять спортом.

Висновки з проведеного дослідження. Таким чином, на підставі аналізу отриманих результатів дослідження, ми дійшли висновку, що домінівною психологічною статтю як у чоловіків, так і в жінок $€$ андрогін. Зважаючи на вищевикладене, можна констатувати, що отримані результати підтверджують тенденцію до маскулінізації дівчат-спортсменок у досліджуваній групі.

\section{ЛІТЕРАТУРА:}

1. Багадирова С.К. Формирование гендерной идентичности в условиях профессионализации личности в спорте. Вестник Адыгейского государ- ственного университета. Серия 3: Педагогика и психология. 2014. С. 12.

2. Берн Ш. Гендерная психология. Законы мужского и женского поведения. Санкт-Петербург : ПраймЕврознак, 2007. 320 с.

3. Дамадаева А.С., Шахов Ш.К. Проблема коррекции гендерных деформаций личности профрессиональных спортсменок. Вестник спортивной науки. 2012. № 12 (2). С. 19-22.

4. Дамадаева А.С. Гендерные аспекты спортивной мотивации. Ученые записки университета имени П.Ф. Лесгафрта. 2011. Вып. 12 (70). С. 58-63.

5. Кулаева Е.В. Самоопределение женщин с различными типами гендерной идентичности : дисс. ... канд .псих. наук : 19.00.05. Ярославль, 2010. 185 с.

6. Лопуга Г.В., Михайленко Ю.М. Особливості застосування психодіагностичних досліджень в навчально-тренувальному процесі спортсменів. Науковий журнал «Габітус». 2020. № 12. С. 168-171.

7. Лопуга Г.В., Михайленко Ю.М., Решетилова В.М. Порівняльна характеристика окремих фрункціональних та психофрізіологічних показників студентів-спортсменів та осіб, які не займаються спортом. Світ психології: освіта, наука, інновації : IX Міжнародні Челпанівські психолого-педагогічні читання у рамках X Міжнародного фестивалю, м. Київ, 14-17 травня 2020 р. Київ : Гнозис, 2019-2020. C. 162-170.

8. Пайнс Э., Маслач К. Практикум по социальной психологии. Санкт-Петербург : Питер, 2000. C. 201-202.

9. Родоманова С.С. Социально-педагогические проблемы гендерных отношений в спорте : авторефр. дисс. ... канд. пед. наук : 13.00.04 ; ГУФК им. П.Ф. Лесгафрта. Санкт-Петербург, 2007. 20 с.

10. Штылёва Л.В. Фактор пола в образовании. Гендерный подход и анализ. Москва : Мир, 2008. 316 с.

11. Усольцева А.А. Особенности становления гендерной идентичности спортсменок условно мужских видов спорта : дисс. ... канд. псих. наук : 19.00.01. Тюмень, 2015. С. 122-123.

12. Уэйнберг Р.С., Гоулд Д. Основы психологии спорта и фризической культуры. Киев, 2001. С. 290.

13. Цикунова Н.С. Гендерные характеристики личности спортсменов в маскулинных и фемининных видах спорта : автореф. дисс. ... канд. пед. наук : 13.00.04. Санкт-Петербург, 2003.19 с.

14. Bem S.L. Gender schema theory and its implications for child development: Raising genderschematic children in a gender-schematic society. Journal of women in culture and society. 1983. Vol. 8. № 4. P. 65-78. 